\title{
Corporate Law as the Ideology of Capitalism
}

The Politics of Law: A Progressive Critique, edited by David Kairys. New York: Pantheon Books, 1982. Pp. ix, 321. \$22.50.*

\section{Jan G. Deutsch $\uparrow$}

[The Politics of Law is a collection of essays from the Critical Legal Studies movement. The essential tenets of this movement include: (1) a rejection of the idea that a distinctly legal mode of reasoning exists; (2) a belief that democratic processes lend a false legitimacy to existing social and economic relations; (3) the assertion that law and the state embody values that prevent their neutrality; and (4) the view that law is an important tool in legitimizing the existing social system. In this review, Professor Deutsch offers a "critical" analysis of the ideological role of law in American society as an alternative to the essays in The Politics of Law.-Ed.]

I.

The United States is a nation forged by revolution. It is also a society whose economic system is denominated "capitalism." In Marxist terminology, revolution is a political event associated with the termination as well as the birth of capitalist values, and ideology is doctrine utilized to produce change.

For political scientists in the United States, the question "Is ideology dead?" seems more important than the question of the nature of American ideology. This emphasis is unfortunate because ideological factors are basic determinants of political action. Indeed, with the exception of personal friendship or economic and political corruption, it is ideological affinity that arguably provides the primary basis for political allegiance. Consequently, the inability of American political science to deal with a political concept of such fundamental importance suggests that ideology must operate within our society in unique and mysterious ways.

Ideology comprises the set of beliefs by which a society expresses acceptance of itself. Ideology is what transforms a group, of whatever size or

* For a review more closely tied to The Politics of Law, see Forbath, Book Review, 92 Yal. L.J. (1983).

$\dagger$ Professor of Law, Yale Law School. 
status, into a social entity. For Marxists, ideology consists of revolutionary action. Yet because revolution may not actually occur at any given time, ideology can also legitimate the status quo.

Historically, religion served to legitimate the status quo, and it is presumably to accommodate this fact that Marxist doctrine denominates religion an opiate. Religion functions as an opiate, however, only when it erects an impregnable wall between the realms of Caesar and of God. It is at that point, when neither the secular nor religious world defines aspirations or limits in the other realm, that religion serves simply to maintain a given state of affairs. But at that point, because it is simply promoting its version of supernatural reality rather than attempting to interact with the circumstances of secular existence, religion as opiate is rendered ineffective as ideology: It becomes ideas incapable of moving people to action. To be effective, ideology must be in the world and of it, for ideology must move large numbers of people to change or preserve the social structure that surrounds them.

Common law is law defined by cases. Since corporate lawyers are paid largely to keep their clients out of court, corporate law is characterized by a relative paucity of precedents. Moreover, abstract propositions derivable from those decisions are not themselves authoritative. Only the holdings arrived at in the process of applying those propositions to the concrete complexities of an actual dispute are properly called law.

It is this process of application that constitutes the constant interaction of law with reality, and thus it is this process that permits law to operate as ideology. Americans have long accepted the proposition that the words of the Bill of Rights impose limits on the power exercised by political authorities. Until the years following World War II, the rights secured by those words had not been seen as granting individuals social and economic, as well as political, entitlements. Only after the Depression forced the New Deal's acknowledgment of the need for governmental intervention in the economy did constitutional law have to take into account the reality of social and economic stratification. Nonetheless, the judiciary, the branch of government most intimately connected with the application of law to reality, is still entrusted with the ideological task of giving reality to the Bill of Rights' promise of according individuals the same respect as the state.

Perhaps law can serve an ideological function only in connection with political rights; perhaps no ideology can legitimate a society that refuses to accept social class as limiting what an individual can do. So long as one believes instead that individual free will can surmount limitations imposed by class designation, however, one can believe that corporate law, viewed as a social mechanism, functions in the economic realm as constitutional 
law does in the political-that the ideals of corporate law define, in connection with economic institutions, the image to which our society aspires.

\section{II.}

Henry Ford symbolizes many things in the history of the United States. Developer of the automobile, promoter of an end to international conflict, family patriarch, opponent of labor unions, he represents an individualism that manifested itself in a variety of political and economic forms during the Nineteenth Gentury. The political manifestation of this individualism was the Progressive movement of the late Nineteenth Century, which advocated "direct" democracy at home (symbolized by such reforms as the initiative, the referendum, and election of judges) and which attempted to restrict involvement in international affairs to "principled" uses of national power (like the convening of conferences and the formulation of agreements in pursuit of ends such as the renunciation by nations of the right to resort to arms). ${ }^{1}$

Progressives believed that the accumulation of capital made possible by the corporate structure permitted persons in control of such entities to wield inordinately large amounts of economic power, a view that sometimes triumphed over even the desire to allow persons to dispose of the fruits of their enterprise. It was this perception that led the Michigan Supreme Court in Dodge v. Ford Motor Co. ${ }^{2}$ to respond to Henry Ford's plan to expand his production facilities while reducing the selling price of his cars (and keeping to a minimum the dividends paid to shareholders) by warning that:

The difference between an incidental humanitarian expenditure of corporate funds for the benefit of the employees, like the building of a hospital for their use and the employment of agencies for the betterment of their condition, and a general purpose and plan to benefit mankind at the expense of others, is obvious. There should be no confusion (of which there is evidence) of the duties which Mr. Ford conceives that he and the stockholders owe to the general public and the duties which in law he and his codirectors owe to protesting, minority stockholders. ${ }^{3}$

The argument made by the Michigan Supreme Court rests on the proposition that only competition, as manifested in the profit motive, puts sufficient pressure on those in control of corporate wealth to prevent abuse

1. For one view of the Progressive movement, see R. Hofstader, The Age of Reform (1955).

2. 204 Mich. 459,170 N.W. 668 (1919).

3. Id. at $506-07,170 \mathrm{~N}$.W. at 684 . 
of their power. ${ }^{4}$ Analogous arguments-that certain competitive practices confer unfair advantages and that the size of certain organizations gives them an unfair competitive advantage-underlie the antitrust legislation limiting the exercise of corporate power.

The dilemma faced by a society characterized by this faith in the competitive ideal is how to justify a system that may injure those who fall short in the contest. The American answer has pointed to success, to a standard of living that far exceeds that of other societies. These economic achievements were accompanied by the growth of corporate entities, a fact that made it difficult to regard size itself as a social evil quite apart from the theoretical argument that only entities as large as the largest factor in any given market could compete on even terms with the leader. ${ }^{5}$

The Dodge v. Ford court, while it forced the payment of dividends which Ford had attempted to discontinue, refused to enjoin the building of a Ford-owned steel plant at River Rouge, which was opposed precisely because it represented too large an agglomeration of economic power. ${ }^{\circ}$ What is most striking is the fact that the Michigan Supreme Court refused to act in the face of claims that Ford, over shareholder objections, was charging less than the market price for his product. "In view of the fact that the selling price of products may be increased at any time," the court held, "the ultimate results of the larger business cannot be certainly estimated. The judges are not business experts."

The rhetoric of Dodge $v$. Ford rests on the importance of the profit motive in disciplining corporate activity. In operational terms, however, the decision permits invocation of the business judgment rubric to shield corporate activity from judicial control. In terms of applying the competitive ideal to ongoing economic activity, in other words, only enactment of the antitrust laws has subjected business entities in the United States to more severe constraints than those imposed by other nations. ${ }^{8} \mathrm{~A}$ satisfactory answer to the question of why we continue to accept the costs of such constraints would encapsulate a great deal of United States history. Such

4. "A business corporation is organized and carried on primarily for the profit of the stockholders. The powers of the directors are to be employed for that end." Id. at 507, 170 N.W. at 684.

5. Indeed, the court rejected the Dodges' contention that a Michigan statute limited the size of an existing corporation on the basis that the statute's history indicated encouragement of the large corporation. Id. at 493-96, 170 N.W. at 679-80.

6. The minority stockholders' complaint involved the proper distribution of dividends, but part of the relief they sought was an injunction against construction of the smelting plant. Id. at 497,170 N.W. at 681 .

7. Id. at 508, 170 N.W. at 684. The results up to the date of the opinion were that the Ford Motor Company had grown in fourteen years from a company with a capital stock of $\$ 150,000$ to one with total assets of over $\$ 132$ million, while the price of its cars dropped from $\$ 900$ to $\$ 360$.

8. In Dodge " Ford, however, the court specifically stated that Ford's proposed expansion did not violate the antitrust laws. Id. at 499,170 N.W. at 681 . For a discussion of allowable monopolies, see United States v. Aluminum Co. of Am., 148 F.2d 416, 429-30 (2d Cir. 1945) (L. Hand, J.). 
an answer-a persuasive description of the power of the competitive ideal-would canvass those historical factors that make possible an underestimation of the significance of limits on individual achievement, those factors that made the New Frontier an effective political slogan during the Kennedy years.

Such factors include a wealth of natural resources. They include as well the United States' freedom from feudalism and thus from the class structures derived from the networks of personal loyalties that provided stability in feudal society. These factors produce the frontier-a social safety valve and a source of relatively costless economic expansion that allows the shifts in distribution accompanying changes in production to be perceived as making more available for all. Though the frontier existed within the territorial United States, nineteenth-century Americans failed to restrict its significance to the domestic arena. This fact permitted Progressives to believe that what worked in the United States could work anywhere-to insist on limiting participation in foreign affairs to "principled" uses of power-and thus to combine support for competition at home with a refusal to accept war as an activity made necessary by the frontier's disappearance.

Viewed from the outside, the frontier produced an innocent certainty about the rightness of what one was doing that easily turned into arrogance when one dealt with those not members of the frontier community. The antitrust precedent that illustrates this proposition is United States $v$. Aluminum Co. of America, ${ }^{2}$ in which Alcoa was charged with attempting to acquire a monopoly in the United States. Foreign manufacturers of aluminum had agreed, through a contract made in Switzerland, to set up a system of export quotas, and evidence was introduced tending to prove that this agreement affected potential imports into the United States. ${ }^{10}$ Though Alcoa's presence in the case was crucial to allow service of process, Alcoa had no direct connection with this quota system, participating only through a Canadian corporation established to hold Alcoa's foreign properties.

Judge Learned Hand, speaking for the Second Circuit, ${ }^{11}$ held that in such circumstances proof of effects on commerce alone was an insufficient basis for liability; proof of intent to control the foreign commerce of the

9. 148 F.2d 416 (2d Cir. 1945).

10. Id. at 444-45. See Note, Application of the Anti-Trust Laus to Extraterritorial Conspiracies, 49 YAle L. J. 1312, 1314, 1318 (1940) (discussing evidence submitted to district court). The district court concluded, however, that effects had not been proven. United States v. Aluminum Co. of Am., 44 F. Supp. 97 (S.D.N.Y. 1941).

11. The Second Circuit in Alcoa was sitting as a court of last appeal pursuant to a certificate from the Supreme Court. 148 F.2d at 421. 
United States was also required. ${ }^{12}$ Although there was no evidence on this question, ${ }^{13}$ the Second Circuit found the requisite intent by relying upon the rule that antitrust defendants are presumed to intend the natural consequences of their acts. ${ }^{14}$ Since the evidence in Alcoa seemed to reveal effects on United States imports, ${ }^{18}$ application of the rule provided a presumption of intent. In cases decided after Alcoa, however, pleas of good intent or lack of intent, apparently even when proved, ${ }^{16}$ have failed to prevent the imposition of liability. ${ }^{17}$ Alcoa is troubling, in other words, not only because it imposes United States policy upon foreign entities, but also because it is not above-board about why it is doing so.

III.

F.D.R.'s political success in mitigating the social impact of the Great Depression is undeniable. He successfully deployed a series of experimental and often contradictory policies so that the public responded with hope rather than exasperation. Only as F.D.R.'s second term drew to an end did it become clear that his economic measures had not produced a sustained recovery. True recovery occurred with World War II, but by then the Great Depression had unraveled the simple correlation between corporate size and economic success that characterized the period of economic growth following the Civil War.

12. Id. at 443-44. This view seems to have been accepted by commentators. See, e.g., DEP'T OF Justice, AtTorney General's National Committee to Study the ANTrrrust LAws 76 (1955); Barron, Foreign Trade-Mark Licensing and American Anti-Trust Laws: Some Observations on the Timken Case, 9 CATH. U.L. REv. 25 (1960).

13. Sep Note, supra note 10 , at 1318.

14. See Addyston Pipe \& Steel Co. v. United States, 175 U.S. 211, 243 (1899).

15. The appellate court stated:

The [district] judge also found that the 1936 agreement did not "materially affect the . . . foreign trade or commerce of the United States"; apparently because the imported ingot was greater in 1936 and 1937 than in earlier years. We cannot accept this finding . . . . It by no means follows from such an increase that the agreement did not restrict imports; and incidentally it so happens that in those years such inference as is possible at all, leads to the opposite conclusion . . . . [T] he proportion of imports to domestic ingot was about 15.6 per cent for the first period and about 12.6 per cent for the second. We do not mean to infer from this that the quota system of 1936 did in fact restrain imports, as these figures might suggest; but we do mean that nothing is to be inferred from the gross increase of imports.

Alcoa, 148 F.2d. at 444.

16. See United States v. National Lead Co., 63 F. Supp. 513, 523, 527 (S.D.N.Y. 1945) (although National Lead was unaware of antitrust consequences of its action, it was found liable together with DuPont, which had sought extensive legal advice on antitrust consequences of its actions), aff'd, 322 U.S. 319 (1947).

17. E.g., United States v. Minnesota Mining \& Mfg. Co., 92 F. Supp. 947, 958 (D. Mass. 1950) (defense of lack of motive not considered); United States v. Timken Roller Bearing Co., 83 F. Supp. 284, 310 (N.D. Ohio 1949) (good intent no defense), aff'd, 341 U.S. 593 (1951); United States v. General Elec. Co., 82 F. Supp. 753, 890-91 (D.N.J. 1949) (although Phillips proved to have knowledge of antitrust laws, question of intent was not considered). Nor was good intent a defense in preAlcoa cases involving conduct within the United States. See Thomsen v. Cayser, 243 U.S. 66, 86 (1917); Standard Sanitary Mfg. Co. v. United States, 226 U.S. 20, 49 (1912). 
The Depression shifted perceptions of economic power, a shift symbolized by a photograph taken in the United States Senate Caucus Room on June 1, 1933. Newspapers ran the picture of an avuncular sixty-twoyear-old in a leather-upholstered armchair with a female midget on his lap. The man in the photograph was J.P. Morgan, the banker who organized the holding companies that dominated various sectors of the American economy. Morgan was waiting to testify before a Senate committee about to condemn the practices of his bank, and the midget (who had been placed on his lap by a press agent) was a member of the Ringling Brothers and Barnum \& Bailey Circus troupe. ${ }^{18}$

Seven years later, Litwin $v$. Allen, ${ }^{19}$ a shareholders' derivative suit against various banks and members of J. P. Morgan \& Co., held that a transaction involving the sale by Allegheny Corporation of certain railroad bonds violated fiduciary principles because it was combined with an option to repurchase. The Van Sweringens, who controlled Allegheny, were one of the group of entrepreneurs identified with the Great Depression, and Allegheny had been organized as a holding company to provide them with funds for investment in railroad securities. The option in question, whose terms were extremely favorable to the Van Sweringens, ${ }^{20}$ resulted from borrowing limitations in Allegheny's charter. ${ }^{21}$ Moreover, because the bonds were convertible, the Van Sweringens insisted on the right of repurchase to avoid the possibility of losing control of the railroad. ${ }^{22}$

As the court noted, "There [was] no case directly in point." that this absence of precedent did not prevent the court from invalidating the transaction underlines the shift in attitude that separates Dodge $v$. Ford from Litwin $v$. Allen: Law made by courts had become a process that functioned not simply to impose limits on the growth of corporations, but also to supervise their business activities. The procedural device which implements this function is the shareholders' derivative suit, and cases on the frontier of corporate law today are delineating the standards of reviewing a corporation's decision not to pursue such a suit.

In Zapata Corp. v. Maldonado, ${ }^{24}$ the Supreme Court of Delaware-recognized as "eminent" as the result of its "unique experience in

18. G. Thomas \& M. Morgan-Witts, The Day the Bubble Burst: A Social. History of The Wall Street Crash of 1929, at 417-18 (1979).

19. 25 N.Y.S.2d 667 (N.Y. Sup. Ct. 1940).

20. The option was for a repurchase at the original sale price. The Van Sweringens therefore bore none of the risk of a drop in the price of the bonds. Id. at 698 . It was this uneven distribution of risk which led the court to hold the defendants liable. Id. at 697-99.

21. Id. at 691-92.

22. Id. at 692 .

23. Id. at 696 .

24. 430 A.2d 779 (Del. 1981). 
the area" of derivative suits ${ }^{25}$-required the trial court to override a corporate decision to discontinue a derivative suit whenever "the Court determines . . . that the [corporation has not demonstrated that the decisionmaking body] is . . . independent [and] has . . . shown reasonable bases for its conclusions, or, if the Court is not satisfied for other reasons relating to the process, including but not limited to the good faith of the [decisionmaking body]. ${ }^{236}$ Moreover, even if a corporation meets this test, the trial court may, "in its discretion," apply "its own independent business judgment . . . [and] when appropriate, give special consideration to matters of law and public policy in addition to the corporation's best interests."27 The Zapata court justified this extraordinary degree of judical review earlier in the opinion:

[N]otwithstanding our conviction that Delaware law entrusts the corporate power to a properly authorized committee, we must be mindful that directors are passing judgment on fellow directors in the same corporation and fellow directors, in this instance, who designated them to serve both as directors and [independent litigation] committee members [charged with deciding whether or not to continue the derivative litigation]. The question naturally arises whether a "there but for the grace of God go I" empathy might not play a role. And the further question arises whether inquiry as to independence, good faith and reasonable investigation is sufficient safeguard against abuse, perhaps subconscious abuse. ${ }^{28}$

The problem posed by Zapata centers on the nature of the judicial task this test requires. The difficulties involved in the probing of "perhaps subconscious" motives are apparent in Globe Woolen Co. v. Utica Gas \& Electric Co. ${ }^{29}$ in which Judge Cardozo upheld a trial court decision voiding a contract between two corporations that shared a common director. It is unclear whether the Globe opinion was based upon the substantive terms of the contract, the fact that negotiations on behalf of one of the corporations had been conducted by a subordinate, or the fact that the director who had conducted the negotiations on behalf of the other corporation held the same position in each of the parties to the contract. What is striking is the presentation of the facts on the basis of which Cardozo held the contract void: "At least, a finding that there was [a relation of trust reposed, of influence exerted, of superior knowledge on the one side

25. Joy v. North, 692 F.2d 880, 891 (2d Cir. 1982), cert. denied sub nom. Citytrust v. Joy, 103 S. Ct. 1498 (1983).

26. Zapata, 430 A.2d at 789 .

27. Id.

28. Id. at 787 .

29. 224 N.Y. 483,121 N.E. 378 (1918). 
and legitimate dependence on the other] has evidence to sustain it",;o "[t]hese elements of unfairness [the common director] must have known, if indeed his knowledge be material";; "[t]he inference that [the common director foresaw the precise evils that developed] might not be unsupported by the evidence."32

In short, the facts are rarely clear, and because it is so difficult to determine whether or not a potential conflict of interest has in fact had an impact on a given transaction, decisions like Globe produced statutes defining in precise terms when a conflict of interest will void contracts or transactions. Such laws have transformed judges making law about conflict of interest into interpreters of statutes. This shift of the judicial role is illustrated by Joy $v$. North, ${ }^{33}$ in which the Second Circuit held that the test enunciated by the Delaware Supreme Court in Zapata was law in the State of Connecticut.

Agreeing that Connecticut cases do not resolve the question whether Connecticut's law is the same as Delaware's, the majority and dissent arrived at conflicting positions by treating as relevant different statutory material. The majority focused on the fact that Connecticut's indemnification statute "adopts the middle ground between no indemnification and permissible indemnification without regard to outcome and thus does not bespeak a negative attitude toward enforcement of fiduciary obligations through meritorious derivative litigation." ${ }^{34}$ While the majority left unclear how the content of the common law governing conflict of interests is defined by statutory provisions regarding rights to indemnification, the dissent fared no better in demonstrating the relevance of its statute. It relied on the opinion of the United States Supreme Court in Burks $v$. Lasker, which held (in a footnote) that "[w]hile lack of impartiality [of disinterested directors] may or may not be true as a matter of fact in individual cases, it is not a conclusion of law required by the Investment Company Act." "ss But the statutory provisions interpreted in Burks $v$. Lasker, while they do deal directly with conflicts of interest, not only are restricted to investment companies but are also a matter of federal rather than state law.

The Joy $v$. North opinions must cite either judicial precedent or statutory authority for the result they reach because of the business judgment rule, which requires judges to rely on something more than the certainty

30. Id. at 490,121 N.E. at 380.

31. Id. at 491,121 N.E. at 380.

32. Id. at 492,121 N.E. at 381.

33. 692 F.2d 880 (2d Cir. 1982), cert. denied sub nom Citytrust v. Joy, 103 S. Ct. 1498 (1983).

34. Id. at 889 .

35. 441 U.S. $471,485 \mathrm{n} .15$ (1979). The dissent in Joy $v$. North cites Burks in 692 F.2d at 900 (Cardamone, J., concurring in part, dissenting in part). 
of hindsight when overturning a business decision as unreasonable. The business decision examined in Joy $v$. North is whether it was reasonable for a bank continually to extend further credit to a builder (presumably in hopes of recapturing some of the moneys already advanced). What the majority eventually rested on was the fact that the builder's

venture . . . is so similar to the classic case of Litwin v. Allen, supra (bank purchase of bonds with an option in the seller to repurchase at the original price, the bank thus bearing the entire risk of a drop in price with no hope of gain beyond the stipulated interest) that we cannot agree with the [Special Litigation Committee of independent directors which recommended dismissal of the suit on the basis of the] conclusion that only a "possibility of a finding of negligence" exists. $^{38}$

To ask whether Joy $v$. North was correctly decided is to assess the precedential significance of Litwin and to attempt to determine whether the Litwin opinion compelled the decision arrived at by the majority in Joy $v$. North. These tasks require us to ask why the Litwin court reached the result it did. The Litwin opinion recognizes precisely why it was so difficult for a judge to arrive at a just result in that case:

[T] he main transactions attacked in this case, those dealing with the purchase of the Missouri Pacific bonds with the option of repurchase to Allegheny Corporation . . . took place in October, 1930. There had been a crash in the stock market in October, 1929. In April, 1930 , there was an upswing in the market. Shortly thereafter there began a slow but steady decline until October, 1930, when there was another severe break. The real significance of what was taking place was, generally speaking, missed at the time, but is plain in the retrospect. Forces were at work which for the most part were unforseeable. Men who were judging conditions in October, 1930, by what had been the course and the experience of past panics thought that the bottom had been reached and that the worst of the depression was over; that any change would be for the better and that recovery might reasonably be envisaged for the near future. Experience turned out to be fallacious and judgment proved to be erroneous; but that did not become apparent until some time in 1931. In order to judge the transactions complained of, therefore, we must not only hold an inquest on the past but, what is much more difficult, we must attempt to take ourselves back to the time when the events here questioned occurred and try to put ourselves in the position of those who engaged in them. ${ }^{37}$

36. Joy v. North, 692 F.2d at 896 .

37. Litwin v. Allen, 25 N.Y.S.2d at 677 (1940). 
Given that retrospective awareness, what seems to me crucial is that the Van Sweringens were valued Morgan customers. Why then was the stipulated interest for the loan/option considered an insufficient basis on which to justify J.P. Morgan's giving of the option? My answer rests on the Litwin court's recognition that "the only [one of the four] transaction[s] [involved in the case] in which it is claimed that a profit was made by directors sought to be held liable is that involving [a private purchase at prices below the market] of Allegheny Corporation common stock from J. P. Morgan \& Co. in January, 1929."38 Of this transaction, the court said "[t]he interest of the individuals who bought privately was speculative," the contention that the Allegheny stock transaction operated on the minds of the directors as a 'favor'." 40 What Litwin held in evaluating the private offer of Allegheny common stock, in other words, is that the fact that a market risk was being taken by those to whom J. P. Morgan sold stock outweighed the fact that the price he charged was below the market; that even a favorable speculative opportunity did not compromise a director's fiduciary duty of acting with undivided loyalty on behalf of the corporation on whose board he sits.

One of J. P. Morgan \& Co.'s business practices, branded an abuse of power by the Senate Committee on Banking and Currency, was the use of "preferred lists" of persons who received holding company stock prior to the time trading was begun. ${ }^{41}$ The Litwin judgment is thus less categorical than that arrived at by the Senate Committee, in that it condemns only the single option transaction in connection with the Allegheny bonds rather than an established "preferred list" practice. Whether this distinction is sufficient to make application of the Litwin holding a justifiable basis for the decision in Joy $v$. North is a question that probes the validity of our societal insistence that legislative rules can validly apply to individuals only with the approval of the judiciary. The essence of this belief is that the opportunities for abuse of power afforded a judge in the process of making law are qualitatively different, not only from the opportunities for abuse of power made possible by the legislative process, but also from those afforded the corporate decisionmaker by the process of meeting real and imagined competitive threats. The question raised, in other words, is the legitimacy of that portion of the Zapata test that permits a court to apply "its own independent business judgment."
38. Id. at 676 .
39. Id. at 690 .
40. Id. at 691.
41. F. Pecora, Wall Street Under Oath 27 (1939). 
IV.

I shall examine the legitimacy of Zapata by focusing on a concrete example. To avoid the ambiguities of the distinction between the promulgation of legal standards and,the finding of determinative facts (a distinction that defines both the responsibility and the limitation placed on the work of an appellate judge), I choose the decision in Dodge v. Ford. The question I pose is whether the actions of Henry Ford were sufficiently "disinterested" to avoid the possibility that they represented the perhaps subconscious abuse of power mentioned in Zapata.

If we look simply at what the Michigan Supreme Court did in Dodge v. Ford, we must conclude that it judged the building of River Rouge as sufficiently disinterested, but reached the opposite conclusion about the withholding of dividends. In terms of our question-whether what Ford is doing is an abuse of power-the Court's distinction is at best a purely formal one. The question thus becomes one of the legitimacy of the power of the appellate judge-why the jurist should have the relatively uncontrolled power to determine whether a given business decision was justifiable. What makes the problem of the responsibility of the appellate judge so intractable, moreover, is that the decision of the court does not make the law; the law is precedent, and precedent is the way the decision arrived at by the trial or appellate tribunal is treated in later opinions. Thus, for instance, Alcoa becomes a troubling decision only when later cases make clear that intent has nothing to do with courts assuming jurisdiction over foreign transactions. ${ }^{42}$

The problem in Dodge v. Ford was created by the fact that Henry Ford's declarations of his intention to put all the company's future earnings back into the business was published throughout the United States in "substantially the following language":

"My ambition," declared Mr. Ford, "is to employ still more men; to spread the benefits of this industrial system to the greatest possible number, to help them build up their lives and their homes. To do this, we are putting the greatest share of our profits back into the business." $" 48$

The problem was that instead of defining his goals in terms of the process of profit maximization, Henry Ford insisted on extolling the benefits of increased economic activity. It was his statement of the ideals motivating

42. See supra note 17.

43. 204 Mich. at 468,170 N.W. at 671. 
his behavior that permitted the court to question the extent to which that behavior was sufficently "disinterested."

Focusing on the particular controversy being adjudicated, however, is not enough. So long as judicial rules are being developed, so long as the process of their application continues to interact with the social reality that law attempts to govern, the court's description of the reality contained in the precedents cited to justify its decision must be sufficiently compelling to serve as a standard for judging future behavior. If it is to remain effective, moreover, the doctrine being promulgated can never become so clearly defined as to be impervious to further change. Thus, the clearer a rule is, the more subject it is to manipulation justified by compliance with its explicit formulation. In systemic terms, in other words, any sufficiently uniform standard of behavior will at some point be exploited through development of an application not derivable from the regularities by which the standard was defined.

The rules that govern acceptance of such innovation (the law that governs the marketplace) both determine individual success and define the behavior of the group of which the individual is a member. This duality permits law to serve simultaneously as a constraint which the skillful can successfully manipulate to their individual advantage and as a norm whose existence everyone must respect. It is also as a result of this duality that the law fulfills an ideological function, i.e., it is acceptance of the competitive ideal of corporate law that transforms individual capitalists into elements of a functioning social structure.

\section{V.}

Whether the ideology of corporate law is functioning to justify revolution or to legitimate the status quo, however, is an unanswerable question. Revolution, signifying the loss of legitimacy, occurs whenever enough individuals are sufficiently dissatisfied that their desire to replace the choices embodied in the present system outweighs their concern over the potentially unsatisfactory consequences of new choices.

For individuals, revolutions involve shifts in the criteria by which they identify themselves as political actors; a successful revolution prompts a sufficient number of individual shifts to produce a change in the political values held by the society. Individual social and political identifications are ordinarily matters governed by habit, by the experience of the past. Revolution can thus be defined (in terms of the individual) as the replace-

44. Indeed, the Dodge v. Ford court described Mr. Ford as intending "to continue the corporation henceforth as a semi-eleemosynary institution and not as a business institution." Id. at 504, 170 N.W. at 683. Mr. Ford's views are discussed at greater length in id. at 505-506, 170 N.W. at 683-84. 
ment of habitual by spontaneous political behavior. Such behavior is ordinarily perceived as a free and disinterested act, although it can, of course, be characterized as the individual's rationalization of the need to accept new social categories. If the revolution succeeds, however, and a shift in social values occurs, new terms that define individuals as political beings come into existence, and the shifts in individual identifications are rationalizations only if there is no such thing as a free act.

In Marxist terms, revolution is defined as the social response to the alienation caused by the division of labor. The division of labor, however, results in the provision of more material goods. To the extent that such goods are perceived as valuable, individual alienation may be a social necessity, an obligation that must be assumed by those who wish to be perceived as behaving in a "disinterested" manner.

The alienation felt by individuals working within a corporation places upon that organization the burden of making activities undertaken for its benefit appear meaningful, even when this means structuring work in ways that are not economically efficient. The last stage of capitalism, in other words, may be a shift from competitive economic entities to a selfsustaining bureaucracy. Whether that stage will in fact occur or, if achieved, will eventually result in revolution depends upon whether the ideal of competition-the ideal that makes corporate law an effective ideology-continues to be attractive, and whether the organization of American society permits rewarding behavior motivated by that ideal. 